Bartın Üniversitesi İktisadi ve İdari Bilimler Fakültesi Dergisi, 2021, Cilt 12, Sayı 23

Bartın University Journal of Faculty of Economics and Administrative Sciences, 2021, Volume 12, Issue 23

E-ISSN: 2148-2497

http://iibfdergi.bartin.edu.tr/

https://dergipark.org.tr/tr/pub/bartiniibf

Araştırma Makalesi, Gönderim Tarihi: 29.01.2021; Kabul Tarihi: 24.05.2021

\title{
Gastronomik Miras: Kelle (Sivas) ${ }^{1}$
}

\author{
Dr. Öğr. Üyesi Aykut ŞiMSSEK \\ Kastamonu Üniversitesi \\ asimsek@kastamonu.edu.tr, Orcid ID: 0000-0002-3317-2330
}

\begin{abstract}
Öz
$\mathrm{Bu}$ çalışmada gastronomik bir miras olan kellenin üretiminin devam ettirilmesi ve öneminin vurgulanması amacıyla yapılış süreci ve tüketicilerin tüketim alışkanlıkları incelenmiştir. Araştırmada veri toplama yöntemi olarak nitel araştırma yöntemlerinden yarı yapılandırılmış görüşme tekniği kullanılmıştır ve iki aşamalı olarak gerçekleştirilmiştir. İlk olarak kellenin yapılış sürecinin incelenmesi için kelle hazırlayan üreticilerle görüşülmüştür. İkinci aşamada ise tüketicilerle görüşmeler yapılmıştır. Yapılan görüşmeler sonucunda kelle satışlarının fazla olduğu, şehir dışından da söz konusu işletmelerden kelle tüketenler tarafından sipariş verildiği belirlenmiştir. Ayrıca kellenin cinsiyet farkı olmaksızın uzun yıllardır tüketildiği ve ağırlıklı olarak kış mevsiminde tercih edildiği sonucuna varılmıştır.
\end{abstract}

Anahtar Kelimeler: Sivas mutfağı, Kelle, Gastronomi

JEL Sınıflandırması: L66, L83, L84

\section{Gastronomic Heritage: Kelle (Sivas)}

\begin{abstract}
In this study, in order to continue the production of the kelle and to emphasize its importance that the process of making the kelle which is a gastronomic heritage and the consumption habits of consumers were examined. Semi-structured interview technique, which is one of the qualitative research methods, was used as data collection method and it was carried out in two stages. Firstly, the kelle producers were interviewed to examine the process of making the kelle. In the second stage, interviews were made with consumers. As a result of the interviews, it is determined that the kelle sales are high and kelle is given order from out of the city. In addition, it is concluded that the kelle has been consumed for many years without gender difference and has been preferred mainly in the winter season
\end{abstract}

Keywords: Sivas cuisine, Kelle, Gastronomy

JEL Classification: L66, L83, L84

\footnotetext{
1 Araştırmanın Kastamonu Üniversitesi Sosyal ve Beşeri Bilimler Araştırma ve Yayın Etiği Kurulu tarafından 30.06.2020 tarih ve 14 nolu Etik Kurulu onay kararı bulunmaktadır.
} 


\section{Giriş}

Gastronomi, ne zaman, nasıl, nerede, ne kadar, hangi şekilde, ne yenileceğine (ve içileceğine) yardımcı olan bir tavsiye veya rehberdir. Bu tür tavsiyeler ve rehberlikler yeme-içme ile ilgili bilgi ve becerilerin kazanılmasını kolaylaştırır. Gastronomi ile birlikte yemek, sadece karın doyurma eyleminden ziyade keyifli bir iletişim ve sosyalleşme halini almaktadır (Santich, 2004: 16). Gastronomi kapsamında yöresel mutfaklar, bir bölgenin profilini destinasyon anlamında geliştirmek ve yükseltmek için kullanılabilecek güçlü araçlardandır (Green ve Dougherty, 2008). Çünkü yiyecek ve içecekler turistlerin göz ardı edemeyecekleri unsurlardır ve özellikle de bazı turistler için en önemli seyahat motivasyonlarındandır (Goeldner ve Ritchie, 2006). Dolayısıyla gastronomi, turistlerin tatil deneyimlerinin ayrılmaz bir parçasıdır (Kivela ve Crotts, 2006: 357). Yiyecek ile kültür arasındaki bağlantı sayesinde de gastronomi turizmi önem kazanmıştır (Hall vd, 2003).

Gastronomi turizmi, bir destinasyonun sahip olduğu yiyecek ve içecekleri keşfetmek, onların tadını çıkarmak ve benzersiz bir gastronomi tecrübesi yaşamak amaciyla yapılan seyahatleri ifade etmektedir (Wolf, 2002). Gastronomi turizmi faaliyetlerine katılan turistlerin bütün aktiviteleri yiyecek ve içeceklerle ilgilidir (Hall vd, 2003) ve karar verdikleri destinasyonların mutfakları hakkında bilgi sahibi olduklarından dolayı gastronomi turizmi belirli turistik yerlerin tanıtılması açısından önemli bir firsat sunmaktadır (López-Guzmán ve Sánchez-Cañizares, 2012: 70). Ayrıca söz konusu turistler için yöresel yemekler büyük önem taşımaktadır. Yöresel yemekler, herhangi bir yörede yaşayan insanların kültürüne yerleşmiş, halk tarafindan diğer yemeklerden üstün tutulan ve gelenek haline gelmiş yemekleri ifade etmektedir (Hatiopğlu vd, 2013). Aynı zamanda kültürel bir değer taşıyan yöresel yemekler kültürel ve sosyal kazanımların bir yansıması olarak görülmektedir (Bertella 2011). Bu kapsamda Türkiye, sahip olduğu yedi coğrafi bölge içerisinde kendine has farklı yemeiçme alışkanlıklarına, farklı tatlara ve yöresel yiyeceklere ev sahipliği yapan mutfaklar bakımından oldukça zengindir. Sivas mutfağı da söz konusu mutfaklardan bir tanesidir. Ayrıca Sivas, sağlık turizmi, kış turizmi ve Divriği ilçesi öncülügüünde kültür turizmi kapsamında Türkiye'nin önemli turizm şehirlerinden bir tanesidir. Dolayısıyla şehri ziyaret eden turistlere yerel kültürü yansıtacak yöresel yemeklerin sunulması onların memnuniyetlerinde etkili olabilecektir (Zengin ve Işkın, 2017: 408). Yöresel yemeklerin destinasyonlar için önemli çekicilik ve rekabet avantajı sağladığı, bölgelerin markalaşması açısından etkili olduğu, ziyaret edilen yerlerde yöresel ürünlerin tercih edildiği (Şengül ve Türkay, 2016), turistlerin sosyal medyada gördükleri bir yöresel yemek fotoğrafının destinasyon seçimlerinde etkili olduğu (Eryılmaz ve Şengül, 2016), turistlerin memnuniyetlerini önemli ölçüde etkilediği çoğu araştırma ile desteklenmektedir (Rand vd, 2003; Kivela ve Crotts, 2006; Alonso ve Liu, 2011). Ayrıca hem yöresel yemek tüketim motivasyonlarının hem de farklı kültürlere ait yemeklerin deneyimlenmesinin bir destinasyonu tekrar ziyaret etme konusunda olumlu bir etkiye sahip olduğu (Bayrakcı ve Akdağ, 2016) görülmektedir. Aynı şekilde Lertputtarak (2012) da yemeğin imajının tekrar ziyaret etme niyetini olumlu bir şekilde etkilediğini belirterek yemek imajını yiyecek ve restoran imajı olmak üzere iki gruba 
ayırmıştır. Yiyecek imajını yöresel ürünlerle hazırlanmış ve kültürel bir deneyimi ifade eden dünyada tanınmış/popüler bir mutfak şeklinde ifade etmiştir. Restoran imajını ise ilgi çekici restoran çeşitliliği, hizmet kalitesi, dekorasyon, atmosfer, makul fiyatlar gibi özellikler kapsamında değerlendirmiştir. Bu kapsamda 200 yıllık üretim geçmişine sahip olan kellenin Sivas için önemli bir rekabet avantajı ve yöresel yemek kültürünün önemli bir parçası olduğunu söylemek mümkündür. Uzun ve zahmetli hazırlanma sürecine rağmen de yöre halkı tarafından büyük ilgi görmektedir. Genellikle koyun ve kuzuların baş kısımlarından hazırlanan kelle daha çok kış aylarında ilgi görmektedir (URL-1). Fırında yaklaşık 16 saat pişirilen kelle balta ile kırılmakta ve kahvaltıda tüketilmektedir (URL-2). Kış aylarının dışında da özellikle ramazan ayında iftar sofralarında ayrı bir yeri vardır (URL-3).

Sivas mutfak kültürü ile ilgili yapılan akademik çalışmalar incelendiğinde unutulmaya yüz tutmuş yöresel yemeklerin belirlenmesine (Şimşek vd, 2017), kırsal turizm kapsamında Sivas yöresel mutfağının incelenmesine (Öztürk ve Arıkan, 2018), gastronomi turizmi kapsamında Sivas mutfağının değerlendirilmesine (Zengin ve Işkın, 2017) yönelik çalışmaların olduğu görülmektedir. Bu durumdan hareketle çalışmada, gastronomik bir miras olan kellenin üretiminin devam ettirilmesi ve öneminin vurgulanması amacıyla yapılış süreci ve tüketicilerin tüketim alışkanlıkları incelenmiştir. Kelle gibi yöresel ürünler gastronomik kimlik, çeşitliliğin arttırılması, ürünlerin korunması açısından önem taşımaktadır. Ancak gün geçtikçe yöresel ürünlerin üretiminde problemler yaşanmaktadır. Bu problemlerden en önemlisi de söz konusu ürünlerin olması gereken değeri görememesi ve pazarlama imkanlarının oluşturulamamasıdır (Töre-Başat, Sandıkçı ve Çelik, 2017: 73). Dolayısıyla bu çalışma yöresel ürünlerin korunması, sürdürülebilirliğinin sağlanması ve coğrafi işaret tescili alabilmesi konusunda ilgili kişi ve kurumların bilgilendirilmesi ve bilinçlendirilmesi açısından önem taşımaktadır. Ayrıca Sivas'ta yaşayan yerel halkla ile birlikte şehri ziyaret edenlerin yemek için öncellikle tercih ettiği yöresel lezzetlerden bir tanesi olan kellenin ilgili literatüre kazandırılması açısından da araştırma önemlidir.

\section{Sivas Mutfağı}

Sivas, gerek tarih boyunca geçiş yollarının üstünde bulunması gerekse de çok sayıda medeniyetlerin izlerini taşıması sebebiyle zengin bir mutfak kültürünü içinde barındırır (Şimşek vd, 2017: 738). Et, tahıl ve hamur işleri bakımından zengin olan (Zengin ve Işkın, 2017: 412) Sivas mutfağında sı̆̆ır ve dana etleri sucuk ve pastırma yapımında kullanılırken mutfaklarda koyun eti daha çok kullanılmaktadır. Pehli, söğüş, sebzeli et, soğanlı et, Sivas tavası ve çirli et gibi yemekler Sivas'ta yapılan et yemeklerindendir. Çorbalara bakıldığında da kışın en çok peskütan çorbası, bahar ve yaz aylarında ise pancar çorbası tüketilmektedir. Ayrıca katıklı çorba, toyga, urumeli (tarhana), kesme ve keş gibi çorbalar da bulunmaktadır. Madımak, evelik, ebegümeci, ısırgan, gelin parmağı gibi otlarla yapılan yemekler de Sivas mutfağının sebze yemeklerini temsil etmektedir (Akt: Ertaş ve Gezmen-Karadağ, 2013: 129). Özellikle madımak mutfaklarda çok sık kullanılmakta ve madımak çorbası, madımak mıhlaması, 
madımaklı börek gibi yemekler yapılmaktadır (Şimşek vd, 2017: 738). Sivas'ın sahip olduğu yöresel yemeklerden örnekler Tablo 1'de gösterilmektedir.

Tablo 1. Sivas İlinin Yöresel Yemeklerinden Örnekler

\begin{tabular}{|c|c|c|c|c|c|}
\hline Corbalar & \multicolumn{2}{|c|}{ Yemekler } & \multicolumn{2}{|c|}{ Hamur İșleri } & Tatlılar \\
\hline $\begin{array}{l}\text { Ayran } \\
\text { Çorbas1 }\end{array}$ & Soğanlı Et & Kelle & Firın Katmeri & Peksimet & Tel Helvası \\
\hline $\begin{array}{l}\text { Bulgur } \\
\text { Çorbası }\end{array}$ & Sivas Köftesi & Haşıl & Furın Pidesi & Sac Ekmeği & Un Helvası \\
\hline $\begin{array}{l}\text { Dügüülcek } \\
\text { Çorbası }\end{array}$ & Sivas Tavası & İçli Köfte & Gevrek & Sac Katmeri & Üzümlü Çorba \\
\hline Ekmek Aş1 & $\begin{array}{l}\text { Sebzeli Sivas } \\
\text { Kebabı }\end{array}$ & Karın Dolması & Gilik & $\begin{array}{l}\text { Sivas Kazan } \\
\text { Simidi }\end{array}$ & $\begin{array}{l}\text { Yufka Böreği } \\
\text { Tatlıs1 }\end{array}$ \\
\hline $\begin{array}{l}\text { Ekmek } \\
\text { Kirmas1 }\end{array}$ & $\begin{array}{l}\text { Şalgam } \\
\text { Dolmas1 }\end{array}$ & Kelecoş & Hingel & $\begin{array}{l}\text { Tandır } \\
\text { Çöreği }\end{array}$ & $\begin{array}{l}\text { Gazete } \\
\text { Baklavası }\end{array}$ \\
\hline $\begin{array}{l}\text { İsskembe } \\
\text { Çorbası }\end{array}$ & $\begin{array}{l}\text { Pancar } \\
\text { Sarmas1 }\end{array}$ & $\begin{array}{l}\text { Kızartma } \\
\text { Köftesi }\end{array}$ & Hızır Kömbesi & $\begin{array}{l}\text { Tandır } \\
\text { Ekmeği }\end{array}$ & Karaş \\
\hline $\begin{array}{l}\text { Katıklı } \\
\text { Çorba }\end{array}$ & Tıpış Köfte & Lahana Sarması & $\begin{array}{l}\text { Kavurma } \\
\text { Eriștesi }\end{array}$ & $\begin{array}{l}\text { Tandir } \\
\text { Ketesi }\end{array}$ & Peynirli Helva \\
\hline $\begin{array}{l}\text { Kavurma } \\
\text { Herlesi }\end{array}$ & $\begin{array}{l}\text { Turşu } \\
\text { Mihlamas1 }\end{array}$ & $\begin{array}{l}\text { Madımak } \\
\text { Kavurması }\end{array}$ & Kırdök & Yağlama & Lokma Tatlısı \\
\hline $\begin{array}{l}\text { Kesme } \\
\text { Çorbas1 }\end{array}$ & Tas Kebab1 & Madımak Pilavı & Kırk Giliği & Yağlı & Hasuda \\
\hline Keş Çorbas 1 & $\begin{array}{l}\text { Pancar } \\
\text { Mihlamas1 }\end{array}$ & $\begin{array}{l}\text { Madımak } \\
\text { Yemeği }\end{array}$ & Lavaş & $\begin{array}{l}\text { Yarımca } \\
\text { Börek }\end{array}$ & Sarığı Burma \\
\hline $\begin{array}{l}\text { Pancar } \\
\text { Çorbası }\end{array}$ & $\begin{array}{l}\text { Mumbar } \\
\text { Dolmas1 }\end{array}$ & Mirik Köftesi & $\begin{array}{ll}\text { Mant1 } & \text { (Su } \\
\text { Böreği }) & \end{array}$ & $\begin{array}{l}\text { Yumurta } \\
\text { Eriștesi }\end{array}$ & Hurma \\
\hline
\end{tabular}

Kaynak: Zengin, B. ve Işkın, M. (2017).

Sivas'ın sahip olduğu bitki örtüsü ve soğuk iklim, toplumsal yapısı, tarihi geçmişi ve geçim kaynaklarıyla oluşan yemek kültürü gastronomi turizmi açısından önemli bir potansiyele sahiptir (Zengin ve Işkıı, 2017: 412). Ayrıca mutfak eşyaları arasında önemli bir yer tutan bıçak Sivas'taki en eski el sanatlarından biridir ve Sivas’taki bıçakçılığın kökeni XII. yüzyıla kadar dayanmaktadır (Mahiroğulları, 2003: 64). Sivas mutfağına yönelik gerçekleştirilen akademik çalışmalar incelendiğinde ise söz konusu çalışmaların sınırlı sayıda olduğu görülmektedir. Zengin ve Işkın (2017), gastronomi turizmi bakımından Sivas mutfağını değerlendirmiş ve Sivas'ın zengin bir mutfak kültürünün olduğunu belirtmişlerdir. Ayrıca hem yemek çeşitliliği hem de işletme kapasitesi anlamında mevcut turistik potansiyele hizmet edebilecek kapasiteye sahip olduğunu ifade etmişlerdir. Öztürk ve Arıkan (2018) ise Sivas yöresel mutfağını kırsal turizm kapsamında değerlendirmişlerdir. Kültürel çeşitlilik ve yöresel yemekler bakımından önemli potansiyele sahip olduğunu belirterek Sivas'ta yöresel lezzetler denildiğinde akla gelen, aralarında kellenin de bulunduğu yemekler hakkında bilgiler vermiş̧lerdir. Şimşek (2020), Sivas mutfağına ait coğrafi işaretli yöresel ürünlerin üretiminin tescil belgelerinde belirtilen standartlara uygun olup olmadığını incelemiştir ve söz konusu ürünlerin genel olarak standartlara uygun şekilde üretildiği sonucuna varmıştır. Şeker ve Hastaoğlu (2020) ise gastronomi turizmi kapsamında Sivas yöresel yemeklerinin mikro ve makro besin öğelerini incelemişlerdir. Yöresel ürünlerin kalori 
değerlerinin nispeten yüksek, hayvansal gıda ağırlıklı ve birçok fonksiyonel gıda bileşenini içeren özellikler gösterdiğini belirtmişlerdir. Şimşek ve arkadaşları (2017) da Sivas ilindeki unutulmaya yüz tutmuş yöresel yemeklerin envanterini çıkarmayı amaçlamışlardır ve eski yıllarda çok sık yapılan ancak günümüzde neredeyse hiç yapılmayan 15 farklı yemek tarifine ulaşmışlardır.

\section{Yöntem}

\subsection{Veri Toplama Yöntemi ve Aracı}

Araştırmada veri toplama yöntemi olarak nitel araştırma yöntemlerinden yarı yapılandırılmış görüşme tekniği kullanılmıştır. Görüşme tekniği, görüşülen kişilerden araştırılan konu ile ilgili derinlemesine bilgiler sağlaması ve bu ayrıntılı bilgilerin görüşme tekniği dışında elde edilmesinin zor olmasından dolayı etkili olmaktadır (Arpacı, Zengin ve Batman, 2012). Veri toplama iki aşamalı olarak gerçekleştirilmiştir. İlk olarak kellenin yapılış sürecinin incelenmesi için kelle hazırlayan üreticilerle görüşülmüş̧ür. İkinci aşamada ise tüketicilerle görüşmeler yapılmıştır. Araştırmanın Kastamonu Üniversitesi Sosyal ve Beşeri Bilimler Araştırma ve Yayın Etiği Kurulu tarafindan 30.06.2020 tarih ve 14 nolu Etik Kurulu onay kararı bulunmaktadır. Araştırma deseni Tablo 2'de yer almaktadır.

Tablo 2. Araştırma Deseni

\begin{tabular}{|c|c|c|c|c|c|}
\hline $\begin{array}{l}\text { Veri } \\
\text { Toplama } \\
\text { Yöntemi }\end{array}$ & Araştırma Amacı & Katılımcılar & $\begin{array}{l}\text { Veri } \\
\text { Toplama } \\
\text { Araci }\end{array}$ & Örneklem & $\begin{array}{l}\text { Verilerin } \\
\text { Raporlaştırılması ve } \\
\text { Analizi }\end{array}$ \\
\hline \multirow[b]{2}{*}{$\begin{array}{l}\text { Nitel } \\
\text { Araştırma }\end{array}$} & $\begin{array}{l}\text { Fırında Kellenin } \\
\text { Yapılıș Süreci }\end{array}$ & Üreticiler & \multirow[b]{2}{*}{ Görüşme } & $\begin{array}{l}\text { Üreticilerin } \\
\text { Tamamı }\end{array}$ & \multirow{2}{*}{$\begin{array}{l}\text { Ses ve Görüntü } \\
\text { Kayıtları } \\
\text { Betimsel Analiz }\end{array}$} \\
\hline & $\begin{array}{l}\text { Tüketicilerin } \\
\text { Tüketim } \\
\text { Alışkanlıkları }\end{array}$ & Tüketiciler & & $\begin{array}{l}\text { Kartopu } \\
\text { Örnekleme İle } \\
\text { Tüketiciler }\end{array}$ & \\
\hline
\end{tabular}

Görüşme formu, konu ile ilgili literatür taraması, doküman incelemesi yapılarak oluşturulmuştur ve alanda uzman kişilerle iletişime geçilerek sorular hakkında fikir alışverişinde bulunduktan sonra son hali verilmiştir (Tablo 3).

Tablo 3. Katılımcılara Yöneltilen Görüșme Soruları

\begin{tabular}{|l|l|}
\hline \multicolumn{1}{|c|}{ Üreticilere Yöneltilen Sorular } & \multicolumn{1}{c|}{ Tüketicilere Yöneltilen Sorular } \\
\hline Kaç yıldır bu işi yapıyorsunuz? & Kaç yıldır kelle tüketiyorsunuz? \\
\hline $\begin{array}{l}\text { Fırında kelle sizce kaç yıldır tüketiliyor? Geçmişi } \\
\text { hakkında bilginiz var mı? }\end{array}$ & Ne kadar sıklıkla tüketirsiniz? \\
\hline Şehir dışından sipariş var mıdır? & Tüketirken hangi baharatları kullanırsınız? \\
\hline Günde ortalama kaç tane satarsınız? & Tüketirken ne içersiniz? \\
\hline Saat kaçta satmaya başlarsınız ve kaçta kelle biter? & Ne zaman tüketirsiniz? \\
\hline Üretim aşamasını ayrıntılı bir şekilde anlatır mısınız? & \\
\hline Tüketicilere tavsiyeniz var mıdır? & \\
\hline
\end{tabular}


Görüşme formunda yer alan sorular Sivas ilinde bulunan bütün kelle üreticilerine yöneltilmiştir ve toplamda 5 üretici ile görüşülmüştür. Tüketicilerle görüşme yapılırken ise kartopu örnekleme yöntemiyle belirlenen 16 kişi araştırma kapsamına alınmıştır. Bu örnekleme yöntemi de örneklem için potansiyel birimleri belirmesinin zor olmasından dolayı (Baştürk ve Taştepe, 2013) tercih edilmiştir. Araştırmaya katılım sağlayan toplam 21 kişi ile Şubat-Mart 2020 tarihleri arasında yüz yüze görüşmeler gerçekleştirilmiştir. Üreticilerle yapılan görüşmeler ortalama 15-20 dakika arasında sürerken tüketicilerle yapılan görüşmeler 10-15 dakika arasında gerçekleştirilmiştir. Görüşmeler esnasında katılımcıların izinleri alınarak ses ve görüntü kayıtları alınmış, verdikleri yanıtlar da görüşme formuna yazılmıştır. Ayrıca toplanan verilerin geçerliliğinin ve güvenirliğinin sağlanması amacıyla çeşitleme yöntemlerinden yöntemsel çeşitleme kullanılmıştır. Bu kapsamda görüşme ile birlikte kellenin üretim ve tüketim sürecinde gözlem yapılarak elde edilen bulgular görüşme bulguları ile teyit edilmiş ve iç güvenirliğe katkı sağlanmıştır. Dış güvenirliğin sağlanması için de araştırma sürecinde araştırmacı kendi konumunu açık hale getirmiş, araştırma süreci açık bir şekilde ifade edilerek veri toplama yöntemi ile ilgili ayrıntılı açıklamalar yapılmıştır (Yıldırım ve Şimşek, 2018).

\subsection{Verilerin Analizi}

Yapılan görüşmeler sonucunda elde edilen verilerin nitel araştırma yöntemleri analiz tekniklerinden betimsel analizleri yapılmıştır. Betimsel analiz kapsamında görüşülen kişilerin verdikleri yanıtların doğrudan alıntıları yapılmış, verilerin tamamını temsil edecek frekans, yüzde değerleri belirlenmiş ve elde edilen bulgular kategorize edilerek yorumlanmıştır. Üreticiler $\mathrm{K} 1, \mathrm{~K} 2 \ldots \mathrm{K}$ şeklinde, tüketiciler ise T1, T2 ... T şeklinde kodlanmış ve veriler de kodlanarak analizler yapılmıştır.

\subsection{Bulgular}

Araştırmaya katılan üreticilerin cinsiyet, yaş ve kellecilik yaptıkları sürelere ilişkin bilgiler Tablo 4'de gösterilmektedir.

Tablo 4. Üreticilere İlişkin Bilgiler

\begin{tabular}{|c|c|c|c|}
\hline Katılımcı & Cinsiyet & Yaş & Süre (Yıl) \\
\hline K1 & Erkek & 44 & 21 \\
\hline K2 & Erkek & 35 & 9 \\
\hline K3 & Erkek & 53 & 35 \\
\hline K4 & Erkek & 42 & 20 \\
\hline K5 & Erkek & 60 & 45 \\
\hline
\end{tabular}

Üreticilerin tamamının erkek olduğu ve yaş aralıklarının 35-60 arasında olduğu görülmektedir. Katılımcıların kellecilik yaptıkları sürelere bakıldığında ise K2 katılımcısının en az süreyle (9 yıl), K5 katılımcısının da en fazla süreyle (45 yıl) yaptıkları görülmektedir. Ayrıca üreticilere kaç yıldır kelle üretildiği sorusu 
yöneltilmiştir ve bir katılımcı hariç diğer katılımcılar en az 200 yıldır kelle üretiminin olduğunu, büyüklerinden bu şekilde duyduklarını ifade etmişlerdir. K2 kodlu katılımc1; "Eskiden tek bir yerde satılırmış. Ancak şimdi Sivas'ta 5 tane kelleci var." şeklinde belirtmiştir. Günde ortalama kaç tane kelle satıldığı ve şehir dışından sipariş alma sorularına katılımcıların tamamı ortalama 200'ün üzerinde kelle satışı olduğu yanıtını vermiş̧lerdir. Ayrıca bir katılımcı günlük 400 kelle satıldığını ifade etmiştir. Üreticilerin tamamı şehir dışından çok fazla sipariş aldıklarını da belirtmişlerdir.

Kellenin genellikle sabah saat 04.00 'de satılmaya başlandığı ve yaklaşık 5 saat içerisinde bütün kellelerin satıldığı sonucuna varılmıştır. Ancak bazı günlerde sabah 05:00'de başlandığ 1 ve en geç 10.00'da tükendiği tespit edilmiştir. Kellenin hazırlanma sürecine ilişkin üreticiler; "Bir gün önce ögle saatlerinde (12.00-13.00) koyun, kuzu ve koç kelleleri, kelle tavası içerisinde hava almayacak şekilde firına yerleştirilir ve odun ateşinde ertesi gün sabah saat 04.00-05.00'e kadar pişer. Yani yaklaşık olarak en az 16 saat pişer. Pişen kelle balta yardımı ile kırllarak servis edilir." açıklamasını yapmışlardır.

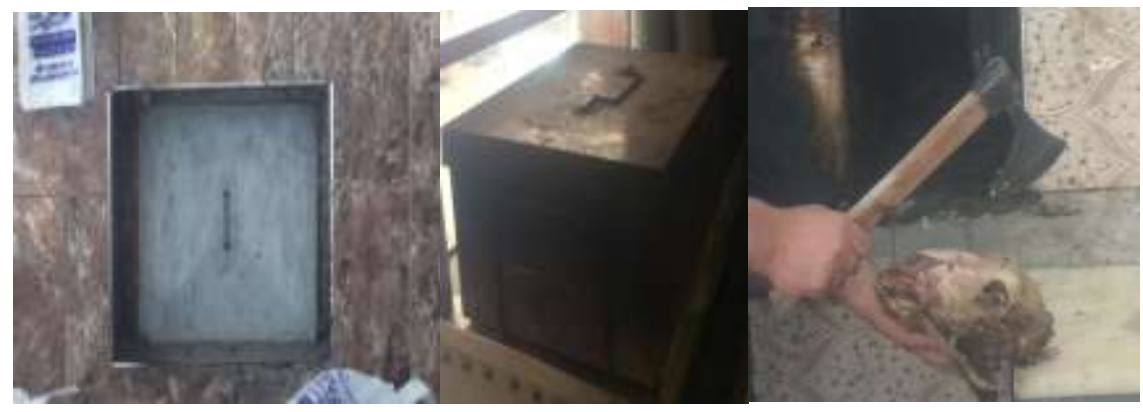

Resim 1. Kelle Fırını, Tavası ve Pişmiş Kelle

Üreticilere son olarak tüketicilere vermek istedikleri tavsiyeler sorulmuştur ve tamamı kuzu kellesinin en lezzetli olduğunu, koyun kellesinden ise çok et çıktığını belirtmişlerdir. Kellenin tok tuttuğunu ve yanak etlerinin çok güzel olduğunu ifade etmişlerdir. Ayrıca tavadaki kellelerden üsttekilerin kızarmış olduğunu, alttakilerin ise yumuşak olduğunu belirtmişlerdir.

Araştırmaya katılan tüketicilerin cinsiyet, yaş ve kelle tükettikleri sürelere ilişsin bilgiler Tablo 5'de gösterilmektedir.

Tablo 5. Tüketicilere İlişkin Bilgiler

\begin{tabular}{|c|c|c|c|}
\hline Katılımcı & Cinsiyet & Yaş & Süre (Yıl) \\
\hline T1 & Erkek & 32 & 22 \\
\hline T2 & Erkek & 31 & 20 \\
\hline T3 & Kadın & 50 & 35 \\
\hline
\end{tabular}




\begin{tabular}{|c|c|c|c|}
\hline T4 & Erkek & 58 & 50 \\
\hline T5 & Erkek & 46 & 30 \\
\hline T6 & Erkek & 36 & 25 \\
\hline T7 & Kadın & 58 & 50 \\
\hline T8 & Erkek & 30 & 22 \\
\hline T9 & Kadın & 58 & 31 \\
\hline T10 & Erkek & 56 & 35 \\
\hline T11 & Kadın & 52 & 25 \\
\hline T12 & Erkek & 28 & 23 \\
\hline T13 & Kadın & 45 & 35 \\
\hline T14 & Erkek & 32 & 15 \\
\hline T15 & Erkek & 35 & 25 \\
\hline T16 & Kadın & 62 & 55 \\
\hline
\end{tabular}

Araştırma kapsamına alınan tüketicilere ilişkin bilgiler incelendiğinde katılımcıların 6'sının kadın, 10’unun erkek olduğu görülmektedir. Yaş aralıklarına bakıldığında 28-62 arasında değiştiği, kelle tüketiminin de 15 yıl ile 55 yıl arasında olduğu tespit edilmiştir. Katılımcıların kelleyi tüketme sıklıkları, mevsimi ve tüketirken kullandıkları baharatlara ilişkin bilgiler Tablo 6'da yer almaktadır.

Tablo 6. Tüketme Sıklığı, Tüketilen Mevsim ve Kullanılan Baharatlar

\begin{tabular}{|c|c|c|c|}
\hline Katılımcı & Tüketme Sıklığı & Tüketilen Mevsim & Kullanılan Baharatlar \\
\hline T1 & Haftada $1 \mathrm{kez}$ & Kış mevsimi ve Ramazan ayı & Kekik, pul biber, tuz \\
\hline $\mathrm{T} 2$ & Yilda $5 \mathrm{kez}$ & Yil boyunca & Kekik, pul biber, tuz \\
\hline T3 & Ayda $1 \mathrm{kez}$ & Kış mevsimi ve Ramazan ay1 & Kekik, pul biber, tuz \\
\hline T4 & Y1lda $6 \mathrm{kez}$ & Kış mevsimi & Kekik, pul biber, tuz \\
\hline T5 & Y1lda 4 kez & Kış mevsimi ve Ramazan ayı & Kekik, pul biber, tuz \\
\hline T6 & Ayda 2 kez & Yil boyunca & Kekik, pul biber, tuz, kimyon \\
\hline $\mathrm{T} 7$ & Y1lda 3 kez & Kış mevsimi & Kekik, pul biber, tuz \\
\hline T8 & Ayda 2 kez & Kış mevsimi ve Ramazan ayı & Kekik, tuz \\
\hline T9 & Y1lda $3 \mathrm{kez}$ & Kış mevsimi & Kekik, pul biber, tuz \\
\hline $\mathrm{T} 10$ & Yilda 5 kez & Kış mevsimi & Kekik, pul biber, tuz \\
\hline T11 & Y1lda 3 kez & Kış mevsimi & Kekik, pul biber, tuz \\
\hline $\mathrm{T} 12$ & Ayda $2 \mathrm{kez}$ & Kış mevsimi & Kekik, pul biber, tuz \\
\hline $\mathrm{T} 13$ & Ayda $1 \mathrm{kez}$ & Kış mevsimi & Tuz \\
\hline T14 & İki Haftada $1 \mathrm{kez}$ & Kış mevsimi & Kekik, pul biber, tuz \\
\hline $\mathrm{T} 15$ & Haftada 2 kez & Kış mevsimi & Kekik, pul biber, tuz \\
\hline T16 & Haftada $1 \mathrm{kez}$ & Kış mevsimi & Kekik, pul biber, tuz \\
\hline
\end{tabular}


Kelle tüketim sıklıkları incelendiğinde haftada bir kez tüketenlerin olduğu gibi yılda üç kez tüketen katılımcıların bulunduğu tespit edilmiştir. Kellenin tüketildiği mevsimin ise ağırlıklı olarak kış mevsimi olduğu görülmektedir. Ancak yıl boyunca ve ramazan ayında iftarda tüketenlerin de olduğu belirlenmiştir. Katılımcıların tamamı kelle yerken kesinlikle tuz kullandıklarını, 15 kişi kekik kullandığını, tercihe bağlı olarak da pul biber ve kimyon da kullanıldığını ifade etmişlerdir. Ayrıca katılımcılar; "Kelle yerken mutlaka ekmek olarak pide yeriz. Kullanılan baharatlar dışında kellenin yanında tere, roka gibi yeşillikler de tüketenler vardır." diye eklemişlerdir.

Katılımcıların kelle yerken yanında tükettikleri içecekler incelendiğinde (Tablo 7) neredeyse tamamının çay içtiği görülmektedir. Ancak sadece bir katılımcı ayran içtiğini ifade etmiştir. Kellenin tüketildiği zaman aralığının ise 06.00'da başladığı, en geç 10.30'da sona erdiği belirlenmiştir. Ayrıca tüketiciler; "Kelleyi daha çok sıklıkla tüketmek istiyoruz fakat özellikle son yıllarda kelle fiyatlarının çok yükselmesi tüketimimizi de etkilemiştir. Bu yüzden ylllara göre tüketimimiz ister istemez azalmaktadır." açıklamasını yapmışlardır ve T13 kodlu katılımcı; "Sivas halkı için kelle çok önemlidir ve kültürel bir değerdir aslında. Anne ve babamızdan gördük ve severek yeriz. Hatta eskiden erkek çocuklar kellenin çene kemiğini tabanca yaparak oynarlardl." şeklinde eklemeler yapmıştır.

Tablo 7. Beraberinde Tüketilen İçecekler ve Tüketme Zamanı

\begin{tabular}{|c|c|c|}
\hline Katılımcı & İçecek & Tüketme Zamanı (Saat) \\
\hline T1 & Çay & $08.00-09.00$ \\
\hline T2 & Ayran & $06.00-10.00$ \\
\hline T3 & Çay & $09.00-10.30$ \\
\hline T4 & Çay & $06.00-08.00$ \\
\hline T5 & Çay & $06.00-08.00$ \\
\hline T6 & Çay & $06.00-10.00$ \\
\hline T7 Çay & $08.00-10.00$ \\
\hline T8 & Çay & $07.00-08.00$ \\
\hline T9 & Çay & $09.00-10.30$ \\
\hline T10 & Çay & $09.00-10.00$ \\
\hline T11 & Çay & $08.00-10.00$ \\
\hline T12 & Çay & $09.00-10.30$ \\
\hline T13 & Çay & $08.00-09.00$ \\
\hline T14 & Çay & $07.00-08.00$ \\
\hline T15 & Çay & $06.00-07.00$ \\
\hline T16 & Çay & $07.00-08.00$ \\
\hline
\end{tabular}




\section{Sonuç}

Sivas ili ile özdeşleşmiş kültürel bir yiyecek olan kellenin yapılış sürecinin incelenmesi ve tüketicilerin tüketim alışkanlıklarının değerlendirilmesi amacıyla gerçekleştirilen bu çalışma kapsamında kelle üreticileri ve tüketiciler ile yarı yapılandırılmış görüşmeler yapılmıştır. Son yıllarda, hayvansal ve tarımsal ürünlerdeki taklit ve tağşişin artması, tüketicilerin daha doğal olduğunu düşündüğü yöresel ürünlerin tüketimini yaygınlaştırmaktadır. Tüketici bilincinin artması ile birlikte de fazla katkı maddesi içermeyen, az işlenmiş ve doğal ürünlerin tercih edilmesi yöresel ürünlerin üretiminin ve pazarlamasının önemini arttırmaktadır. $\mathrm{Bu}$ kapsamda ürünlerin üretiminden pazarlanmasına kadar her aşaması tüketici istek ve tercihlerine göre şekillenerek kalite, fiyat beklentisi gibi (Kadanalı ve Dağdemir, 2016; 15) etkenler önemli rol oynamaktadır.

Üreticilerle yapılan görüşmeler sonucunda gastronomik bir miras niteliğindeki kellenin 200 y1llık bir üretim geçmişine sahip olduğu tespit edilmiştir. Ancak kellenin geçmişi ile ilgili verilen bilgiler üreticilerin tecrübelerine, usta çırak ilişkisine ve duyumlarına göre belirtilmiştir. Seçim de (2018) Konya etli ekmeğinin genel özelliklerini incelediği çalışmasında tarihçe hakkında; etli ekmeğin ne zaman yapıldığının net olarak bilinmediğini, görüşme yapılan kişilerin görüş ve duyumlarına göre bilgiler aktardığını ifade etmiştir. Ayrıca kellenin üretim süreci detaylandırılarak pişirilmesine yönelik önemli noktalara ulaşılmıştır.

Tüketicilerle yapılan görüşmeler sonucunda kellenin yöresel yemekleri arasında oldukça önemli olduğu, ağırlık olarak kış mevsiminde kahvaltı için kültürel bir ürün olduğu sonucuna varılmıştır. Günümüzde uygulanan yüksek fiyatlar sebebiyle tüketicilerin satın almasını olumsuz yönde etkilediği de çalışma sonuçları arasında yer almaktadır. Ancak Köksal (2014) ise yöresel bir ürün olan ceviz ezmesinin pahalı olmasına rağmen tüketicilerin pahalı olarak görmediklerini ve satın alma davranışlarına yönelik olumsuz bir etki göstermediğini belirtmiştir.

Bölgesel kültürün sembolik özelliklerini yansıtan yöresel ürünler, destinasyonun çekiciliğini arttırarak turistleri yerel kültüre yakınlaştıran ürünler olarak bilinmektedir (Sormaz vd., 2019). Bu çalışma da Sivas yöresi için sembolik bir ürün olan kellenin incelenmesi bakımından önem taşımaktadır ve çalışma sonuçlarından hareketle söz konusu ürünün değerli bir gastronomik ürün olduğunu söylemek mümkündür. Dolayısıyla bu ürünün tanıtılması ve pazarlanması önem taşımaktadır. Yöresel ürünlerin pazarlanmasına yönelik ortak sorunlar incelendiğinde, genellikle pazarlamanın küçük işletmeler tarafından yürütülüyor olması, güncel ve teknik pazarlama yaklaşımlarından uzak kalma ya da tutundurma faaliyetlerini etkin kullanamama olduğu görülmektedir. Bu kapsamda söz konusu küçük işletmeler birlikte hareket ederek sorunları ortak bir akılla çözme çabasına girebilirler (Köksal, 2014: 167). Ayrıca hem kellenin hem de benzer yöresel ürünlerin öneminin vurgulanması ve üretiminin devam ettirilmesi için akademik çalışmaların sayısı arttırılabilir. Bu kapsamda ulusal ve uluslararası turizm, 
gıda ve yiyecek fuarlarında tanıtımı yapılabilir. Kültürel bir değer olan kellenin gelecek kuşaklara aktarılması amacıyla coğrafi işaret alınarak tescili sağlanabilir. Böylece kellenin gerek koruma altına alınması gerekse de coğrafi işaretli olmasından dolayı önemli bir pazarlama aracı haline gelmesinin kolaylaşacağı söylenebilir. Coğrafi işaret ile tescillenmiş ürünler üretildiği bölgeyi bir çekim merkezi haline getirebilmektedir ve ürünlere ait standartların ve kalite seviyesinin teminatı anlamına gelmektedir. Ürünün gerçek üreticilerine de katma değer sağlamaktadır (Yalçın, 2013: 208). Ayrıca coğrafi işaretli ürünlerin tüketicilerin daha fazla ödeme isteğini olumlu yönde etkilediği (Teuber, 2011; Toklu, Ustaahmetoğlu ve Öztürk-Küçük, 2016; Toklu, 2016; Dokuzlu vd., 2019) akademik çalışmaların sonuçlarında görülmektedir.

Sivas ilinin sahip olduğu tarihi ve kültürel değerler ile kelle gibi gastronomik ürünler entegre edilerek gastronomi turizmine yönelik seyahat motivasyonları sağlanabilir. Yöresel ürünlerin bir yöreyi temsil etmesi sebebiyle siyasi iradenin bu ürünlere sahip çıkmasının (Köksal, 2014) tanıtım ve tutundurma çalışmalarını güçlendireceğini de söylemek mümkündür. Özellikle kellenin tanıtımına yönelik etkinliklerin planlaması ve şehir dışından alınan siparişlerin arttırılabilmesi için ürünün saklama süresini uzatacak inovatif uygulamalar geliştirilebilir. Ayrıca gelenekselliğinin korunması ve üretimin devam etmesi için kelle üreticilerinin yanında çırak yetiştirilmesine önem verilmelidir. Sürdürülebilir bir gastronominin oluşturulmasında yöresel ürünlerin ve yemeklerin devamlılığının sağlanması, geleneksel tariflerin ve mutfağın gelecek nesillere aktarılması büyük önem taşımaktadır (Yurtseven, 2011). Yöresel bir yemeğin gelenekselliğini veya yöresel kimliğini kaybetmesi durumunda kendine has özelliklerini ve lezzetini de kaybedecektir. Bu durumda sürdürülebilirliği tehlikeye girerek devamlılığı sağlanamayacaktır (Babat, Gökçe ve Varışl1, 2017: 817).

\section{Kaynakça}

Alonso, A. D. ve Liu, Y. (2011). The Potential for Marrying Local Gastronomy and Wine: The Case of The 'Fortunate Islands', International Journal of Hospitality Management, 30, 974-981.

Arpac1, Ö., Zengin, B. ve Batman, O. (2012). Karaman'ın Mağara Turizmi Potansiyeli ve Turizm Açısından Kullanılabilirliği. Karamanoğlu Mehmetbey Üniversitesi Sosyal ve Ekonomik Araştırmalar Dergisi, 14(23), 59-64.

Babat, D., Gökçe, F. ve Varışlı, A. (2017). Hatay Mutfak Kültürünün Sürdürülebilirliğinde, Yöresel Yiyecek Üreticilerinin Rolü. 1st International Sustainable Tourism Congress, 816-830.

Baştürk, S. ve Taştepe, M. (2013). Evren ve Örneklem. Editör: S. Baştürk, Bilimsel Araştırma Yöntemleri (ss. 129-159), Ankara: Vize Yayıncılık. 
Bayrakc1, S. ve Akdağ, G. (2016). Yerel Yemek Tüketim Motivasyonlarının Turistlerin Tekrar Ziyaret Eğilimlerine Etkisi: Gaziantep'i Ziyaret Eden Yerli Turistler Üzerine Bir Araştırma. Anatolia: Turizm Araştırmaları Dergisi, 27(1), 96-110.

Bertella, G. (2011). Knowledge In Food Tourism: The Case of Lofoten and Maremma Toscana, Current Issues in Tourism, 14 (4): 355-371.

Dokuzlu, S., Demir, B., Bilal, Ü. R. Ü. M., Güler, V., Yavuz, S. A. R. I., Yıldız, G. ve Aksoy, O. (2019). Tüketicilerin Yöresel Ürün Satın Alma Davranışları: DAP Bölgesi Ürünleri. Tarım Ekonomisi Dergisi, 25(1), 97-108.

Ertaş, Y., ve Gezmen-Karadağ, M. (2013). Sağlıklı Beslenmede Türk Mutfak Kültürünün Yeri. Gümüşhane Üniversitesi Sağllk Bilimleri Dergisi, 2(1), 117136.

Eryılmaz, B. ve Şengül, S. (2016). Sosyal Medyada Paylaşılan Yöresel Yemek Fotoğraflarının Turistlerin Seyahat Tercihleri Üzerindeki Etkisi. Uluslararası Türk Dünyası Turizm Araştırmaları Dergisi, 1(1), 32-42.

Goeldner, C. R. ve Ritchies, B. J. (2006). Tourism: Principles, Practices and Philosophies (10th Ed.). New Jersey: John Wiley and Sons, Inc.

Green, G. P., ve Dougherty, M. L. (2008). Localizing Linkages for Food and Tourism: Culinary Tourism As A Community Development Strategy. Community Development, 39(3), 148-158.

Hall, C.M. ve Sharples, L. (2003). The Consumption of Experiences or The Experience of Consumption? An Introduction to The Tourism of Taste. Editörler: C.M. Hall, L. Sharples, R. Mitchell, N. Macionis, ve B. Cambourne, Food Tourism Around The World: Development, Management, and Markets (pp. 1-24). Oxford: Butterworth-Heinemann, Elsevier.

Hatioğlu, A. Zengin, B. Batmaz, O., ve Şengül, S. (2013). Yöresel Yemeklerin, Kırsal Turizm İşletmeleri Mönülerinde Kullanım Düzeyleri: Gelveri Örneği. Uluslararası Sosyal ve Ekonomik Bilimler Dergisi, 3 (1), 06-11.

Kadanalı, E. ve Dağdemir, V. (2016). Tüketicilerin Yöresel Gıda Ürünleri Satın Alma İstekliliği. Gaziosmanpaşa Üniversitesi Ziraat Fakültesi Dergisi, 33(1), 9-16.

Kivela, J.J. ve Crotts, J.C. (2005). Gastronomy Tourism, Journal of Culinary Science \& Technology, 4 (2-3), 39-55.

Köksal, Y. (2014). Yöresel Ürünlerin Ulusal Pazarlara Açılmasında Karşılaşılan Pazarlama Sorunları ve Çözüm Önerileri; Burdur Ceviz Ezmesi Örneği. Atatürk Üniversitesi İktisadi ve İdari Bilimler Dergisi, 28(3), 159-171. 
Lertputtarak, S. (2012). The Relationship Between Destination Image, Food Image, and Revisiting Pattaya, Thailand. International Journal of Business and Management, 7(5), 111-121.

López-Guzmán, T., ve Sánchez-Cañizares, S. (2012). Gastronomy, Tourism and Destination Differentiation: A Case Study In Spain. Review of Economics \& Finance, 1, 63-72.

Mahiroğulları, A. (2003). XIX. Yüzyılın Ortalarından Birinci Dünya Savaşına Kadar Sivas' in Sosyo Ekonomik Yapısı. Sosyoloji Konferanslarl, (27), 49-73.

Öztürk, İ., ve Arıkan, V. (2018). Kırsal Turizm Kapsamında Sivas'ın Yöresel Mutfăğ. International Rural Tourism And Development Journals, 2(1), 23-28.

Rand, G. E. D., Heath, E., ve Alberts, N. (2003). The Role of Local and Regional Food In Destination Marketing: A South African Situation Analysis. Journal of Travel \& Tourism Marketing, 14(3-4), 97-112.

Santich, B. (2004). The Study of Gastronomy and Its Relevance to Hospitality Education and Training. International Journal of Hospitality Management, 23(1), 15-24.

Seçim, Y. (2018). Yöresel Bir Ürün Olan Konya Etliekmeği ve Genel Özellikleri Hakkında Nitel Bir Çalışma. Journal of Tourism and Gastronomy Studies, 6(4), 197-209.

Sormaz, Ü., Onur, N., Güneş, H. F. ve Nizamlığlu, H. F. (2019). Türk Mutfağ1 Geleneksel Ürünlerinde Yöresel Farklılıklar: Tarhana Örneği. Aydın Gastronomy, 3(1), 1-9.

Şeker, İ.T. ve Hastaoğlu, E. (2020). Gastronomi Turizmi Kapsamında Sivas Yöresel Yemeklerinin Mikro ve Makro Besin Öğelerinin İncelenmesi. Atatürk Üniversitesi Sosyal Bilimler Enstitüsü Dergisi, 24 (4), 1879-1894.

Şengül, S. ve Türkay, O. (2016). Yöresel Mutfak Unsurlarının Turizm Destinasyonu Seçimindeki Rolü (Mudurnu Örneği). Uluslararası Yönetim İktisat ve İşletme Dergisi, 12(29), 63-87.

Şimşek, A. (2020). Coğrafi İşaretli Yöresel Ürünlerin İncelenmesi: Sivas Mutfağ1 Örneği. Safran Kültür ve Turizm Araştırmaları Dergisi, 3(3), 317-327.

Şimşek, A., Türkmendağ, T., ve Türkmendağ, Z. (2017). Unutulmaya Yüz Tutmuş Yöresel Yemeklerin Turizm Potansiyeli Sağlamadaki Önemi: Sivas İli Örneği. Uluslararası Kültürel Miras ve Turizm Kongresi, Konya, 737-746. 
Teuber, R. (2011). Consumers' and Producers' Expectations Towards Geographical Indications. British Food Journal. 113 (7): 900-918.

Toklu, İ. T. (2016). Tüketiciler Coğrafi İşaret İçin Daha Fazla Ödemek İster Mi? Artvin Balı Üzerine Bir Araştırma. Karadeniz Araştırmaları, (52), 171-190.

Toklu, İ. T., Ustaahmetoğlu, E. ve Öztürk Küçük, H. (2016). Tüketicilerin Coğrafi İşaretli Ürün Algısı ve Daha Fazla Fiyat Ödeme İsteği: Yapısal Eşitlik Modellemesi Yaklaşımı. Journal of Management \& Economics, 23(1), 145-161.

Töre-Başat, H., Sandıkçı, M. ve Çelik, S. (2017). Gastronomik Kimlik Oluşturmada Yöresel Ürünlerin Rolü: Ürünlerin Satış ve Pazarlanmasına Yönelik Bir Örnek Olay İncelemesi. Journal of Tourism and Gastronomy Studies, 5(2), 64-76.

URL-1: (https://www.hurriyet.com.tr/kelle-kirdirmak-icin-sabah-firinlara-akin-edi40661987)

URL-2: (https://www.haberler.com/elle-yenen-kelle-sivas-ta-kahvalti-sofralarinin9574851-haberi/)

URL-3: (https://www.buyuksivas.com/kuzu-kelle/)

Wolf, E. (2002). Culinary tourism: A Tasty Economic Proposition. http://www.culinarytourism.org/faq.php

Yalçın, B. (2013). Yöresel Ürünlerin Pazarlanması Üzerine Değerlendirmeler. Akdeniz Sanat Dergisi, 6(11), 205-213.

Yıldırım, A. ve Şimşek, H. (2018). Sosyal Bilimlerde Nitel Araştırma Yöntemleri. Ankara: Seçkin Yayıncılık.

Yurtseven, H. R. (2011). Sustainable Gastronomic Tourism In Gokceada (Imbros): Local and Authentic Perspectives. International Journal of Humanities and Social Science, 1(18), 17-26.

Zengin, B. ve Işkın, M. (2017). Yerel Mutfakların Gastronomi Turizmi Açısından Değerlendirilmesi: Sivas Örneği. Akademik Sosyal Araştırmalar Dergisi, 5 (40), 404-415. 